\title{
Geothermal Energy in Colombia as of 2018*
}

Energía geotérmica en Colombia hasta 2018

Received: November 21, 2018 | Accepted: June 28, 2019 | Published: February 24, 2020

\section{David Alejandro Moreno-Rendón ${ }^{a}$}

Universidad de Medellín, Medellín, Colombia.

ORCID: 0000-0003-0405-4308

Idalia Jacqueline López-Sánchez

Universidad de Medellín, Medellín, Colombia.

ORCID: 0000-0003-0531-9478

\section{Daniela Blessent}

Universidad de Medellín, Medellín, Colombia.

ORCID: 0000-0002-8347-381X

${ }^{*}$ Review article

${ }^{a}$ Corresponding author. Email: damoreno@udem.edu.co

DOI: https://doi.org/10.11144/Javeriana.iyu24.geic

\section{How to cite this article:}

D. A. Moreno-Rendón, I. J. López-Sánchez, and D. Blessent, "Geothermal energy in Colombia as of 2018," Ing. Univ., vol. 24, 2020. https://doi.org/10.11144/Javeriana.iyu24.geic 


\section{Abstract}

Colombia is a country with great potential for the exploitation of geothermal energy due to its high volcanic activity caused by the subduction between the Nazca and South American tectonic plates. However, this energy is yet to be exploited. This article seeks to describe, by means of a literature review and information processing, the current status of geothermal energy in Colombia, including the current regulations, the limitations, the recommendations to develop the geothermal energy, and some of the most important projects, studies, and research papers that have been emerged on the discovery, exploration, and exploitation of geothermal energy within the country, emphasizing the areas where exploration projects have been initiated, such as the Nevado del Ruiz volcano, the TufiñoChiles-Cerro Negro volcanic system, the Azufral volcano geothermal area, and the Paipa geothermal area. Over the years, energy vulnerability in Colombia and a government policy of fostering sustainable development in different territories have generated favorable conditions for the exploitation of geothermal resources. Nevertheless, there are several technical, infrastructural, legal, and institutional barriers that slow the proper development of these projects.

Keywords: geothermal resources; Colombia; renewable energies

\section{Resumen}

Colombia es un país con gran potencial para la explotación de energía geotérmica, debido a su alta actividad volcánica generada por la subducción de la placa tectónica de Nazca bajo la placa sudamericana. A pesar de esto, en el territorio colombiano dicha energía todavía no se ha explotado. El artículo busca describir, mediante la revisión bibliográfica y el procesamiento de la información, el estado actual de la geotermia en Colombia, mencionando normatividad vigente, limitaciones, recomendaciones para el desarrollo de la energía geotérmica y algunos de los proyectos, estudios e investigaciones más importantes que se han dado sobre el reconocimiento, la exploración y explotación de la energía geotérmica en el país, haciendo hincapié en áreas donde ya se hayan iniciado proyectos de exploración, como el volcán nevado del Ruiz, el sistema volcánico Tufiño-Chiles-Cerro, el área geotérmica del volcán Azufral y el área geotérmica de Paipa. La vulnerabilidad energética en Colombia y la política de Estado de incentivar el desarrollo sostenible de los territorios han generado, a través de los años, condiciones favorables para la explotación de los recursos geotérmicos. Sin embargo, aún existen barreras técnicas, de infraestructura, legales e institucionales que ralentizan el funcionamiento adecuado de estos proyectos.

Palabras clave: recursos geotérmicos; Colombia; energías renovables 


\section{Introduction}

According to a report from the Mining and Energy Planning Unit (UPME) [1], approximately $70 \%$ of the electric power in Colombia comes from hydroelectric power plants, $29 \%$ comes from fossil fuels (coal, diesel, fuel oil, and gas-fired power plants), and 1\% comes from other sources (biomass, wind and solar power); these data illustrate Colombia's substantial dependence on hydroelectric plants, whose conditions and electricity generation are governed by climate and whose environmental impacts are widely questioned [2]-[4]. A high percentage of the electric power in Colombia is still generated by fossil fuels, and almost none of the electric power comes from renewable energies.

Geothermal energy is defined as energy contained as heat within the Earth that is transferred to the surface and can subsequently be used. This heat originates in the internal structure of the planet and is produced by physical processes that take place within the surface [5]. Fumaroles, geysers, and hot springs are observable phenomena on the surface on the planet that show the heat that comes from the ground. Some applications of geothermal resources are building and water heating, balneology, greenhouse and soil sterilization, food processing, textile drying, and power generation.

Volcanic activity in Colombia is generated by the subduction of the Nazca tectonic plate under the South American plate. This phenomenon generates geothermal power, which can be seen in the high volcanic and hydrothermal activity in the central and western mountain ranges of the country. The most studied geothermal regions in Colombia have been the Paipa geothermal areas, the Chiles-Cerro Negro volcanic system, and the Nevado del Ruiz Volcano System (NRV) [6].

According to several studies published since 1968, predominantly carried out by the Latin American Energy Organization (OLADE), the Servicio Geológico Colombiano (SGC), the National University of Colombia, the Caldas Hydroelectric Power Station (CHEC) belonging to the Empresas Publicas de Medellín (EPM) group, and ISAGEN (a former government company that since 2016 has become a subsidiary of the Canadian Brookfield Asset Management group) in Colombia, there are several geothermal areas that could potentially be used to establish geothermal energy generation projects (Figure 1). However, this resource is currently not being exploited in the country. 
Figure 1. Areas with the potential for geothermal development in Colombia

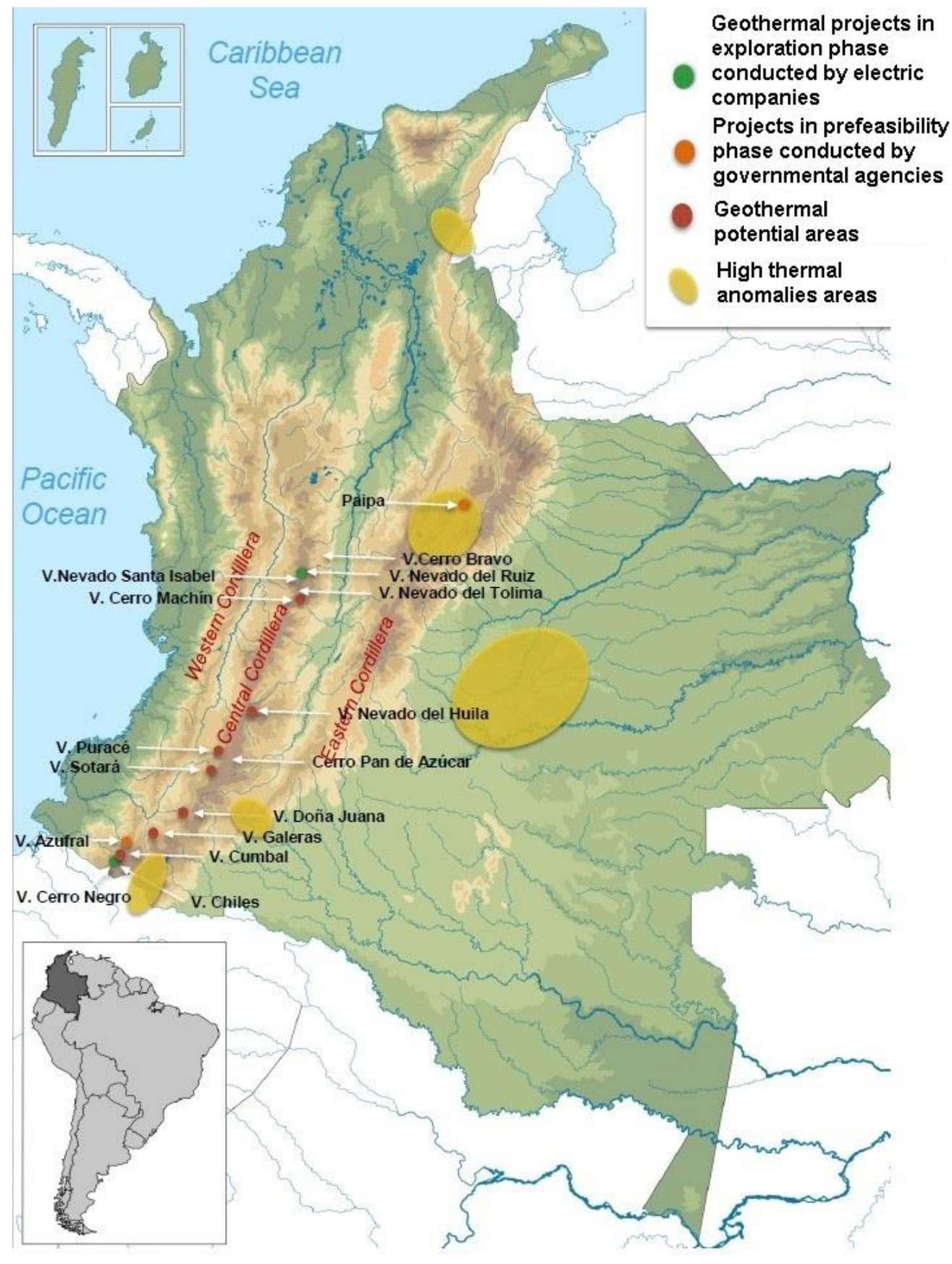

Source: Mejía et al. [7].

This article aims to be a starting point for future research, by describing the current status of geothermal energy in Colombia, describing the current regulations, the limitations, and some of the most important projects, studies, and research papers that have been performed on the recognition, exploration, and exploitation of geothermal energy in the country. 
This article will describe some of the areas with the greatest potential for the development of geothermal energy where exploration projects have been initiated, such as the Nevado del Ruiz volcano, located at the border between the Caldas and Tolima departments; the TufiñoChiles-Cerro Negro volcanic system, located at the border between Colombia and Ecuador; the Azufral volcano geothermal area, located in the department of Nariño; and the Paipa geothermal area, located in the Department of Boyacá.

\section{Areas with geothermal potential in Colombia}

\section{Nevado del Ruiz Volcano}

\section{Previous Studies}

In 1968, the Italian company Ente Nazionale per la Energia Elettrica (ENEL), in collaboration with the CHEC, performed the first geothermal study of the Nevado del Ruiz volcanic complex. In this research, lithological-stratigraphic characteristics, volcanology, structural events, and the hydrogeological system were described to determine the existence

of favorable conditions for the circulation of fluids that may be used in the generation of electric power [8].

In 1983, the CHEC performed a pre-feasibility study for the development of a geothermal project in the Nevado del Ruiz volcanic complex, where detailed conclusions of the origins and evolution of the hydrothermal system associated with the volcano were drawn. In addition, properties such as $\mathrm{pH}$, conductivity, temperature, and other parameters of the hydrothermal system, were determined [9].

The only geothermal exploration well in Colombia (Nereidas 1) was drilled in 1997 by GEOANDINA S.A. (GESA) on the western flank of the NRV. The well reached a maximum depth of 1469 meters and crossed seven lithological units with hydrothermal alteration. The temperature measured at the bottom of the well was approximately $200^{\circ} \mathrm{C}$; however, the study suggested a geothermal reservoir with higher temperatures as the presence of an epidote in the basement indicates temperatures above $250^{\circ} \mathrm{C}[10]$. 
In 2000, INGEOMINAS published the first geothermal map of Colombia wherein the interpolated temperature at a depth of $3 \mathrm{~km}$ is shown, which is considered a feasible depth from the point of view of drilling costs for the development of deep geothermal projects [11].

Recent research (2010-2014) related to the geothermal resources of the Nevado del Ruiz volcanic complex has been carried out mainly by ISAGEN, the SGC, CHEC, the National University of Colombia and the Administrative Department of Science, Technology and Innovation (COLCIENCIAS). Forero [12] characterized the hydrothermal alterations in the northwestern flank of the NRV via petrographic analysis, X-ray diffraction, and the stable isotope ratio in thermal waters. Mejía et al. [13] conducted a study of the structural geology around the NRV from aerial photographs, tectonic morphological features, fault striae data, and stress field calculations. In this study, hydrothermal activity to the west of the NRV was assumed to be caused by the structural controls of the area. Rayo [14] developed a model of the geochemical and thermal evolution of the volcano from petrographic, microstructural, and chemical analyses of minerals and rock geochemistry. That same year, Rojas [15] presented a study of the relationship between the magnetic susceptibility and the electrical and thermal conductivity of the Nevado del Ruiz volcanic system based on geophysical information, such as geoelectric, magnetometric, and magnetotelluric data and well records. Almaguer [16] conducted a magnetotelluric study in the northern sector of the NRV, determining the areas of high electrical conductivity associated with anomalous temperatures, which are of great interest for geothermal energy.

Mejía et al. [7] performed updated research on the Ruiz volcanic complex, which included the drilling of three exploratory wells with depths ranging from 174-300 $\mathrm{m}$ in 2011 . These authors also constructed a geothermal conceptual model and suggested locations for five new exploratory wells with depths ranging from $1.7-2.7 \mathrm{~km}$. These authors mentioned that the next stage would be the drilling of wells, the evaluation of the reservoir, the planning of the field, and the design of a geothermal plant. In this study, the construction and operation of a $50 \mathrm{MW}$ plant was projected for 2018 [7].

González-García and Jessell [17] presented a 3D geological model of the Ruiz-Tolima volcanic massif to assess the uncertainty of the area. Consequently, a more rigorous representation of the geology of the volcanic complex was obtained, reinforcing the information available about this area.

A study of the geothermal potential in the NRV was performed by Vélez et al. [18] via evaluation of the thermal properties of rocks and the construction of a $2 \mathrm{D}$ numerical model 
of heat transfer and groundwater flow in a geological profile located in the northwestern area of the NRV.

Ceballos [19] and Ossa [20], with the support of the CHEC, performed a cartographic, geological, and structural analysis of an area within a geothermal project in the Nereidas Valley, where 6 zones were suggested as possible locations for exploratory wells, with several of these locations defined by zones of dilatational tectonic syntax formed between two faults with opposing movements, which will produce sunken and fractured topographic zones and promote the groundwater flow.

In 2018, Moreno et al. [21] performed 2D modeling of groundwater flow and heat transfer in a fractured geothermal reservoir in the northwestern area of the NRV. This work concludes and validates that secondary permeability, represented mainly by local and regional geological faults, behaves as a natural conduit that connects the surface with deep geological environments, and it is responsible for the hydrothermal activity observed on the surface.

Currently, the University of Medellín is working to characterize and model a fractured geothermal reservoir to the northwest of the NRV and to characterize hot springs in the Nereidas-Botero Londoño area via geochemical analyses [18], [21].

\section{Current situation and projections}

Two projects with pre-feasibility status for the development of geothermal energy in the NRV are currently being executed by the ISAGEN and CHEC companies.

Since 1994, GESA, a subsidiary of CHEC, has had an environmental license for the geothermal project, which has allowed GESA to advance a deep-drilling design and determine the potential in the Nereidas Valley area [22]. ISAGEN requested an environmental license in February 2014 for a 50-MW geothermal generation project in the Ruiz volcanic massif (areas A and B) [23]. However, this license has not yet been granted by CORPOCALDAS, the Environmental Authority that oversees this project.

According to a lecture by Ramírez [24] at the National Geothermal Meeting (RENAG) 2017, some issues that CORPOCALDAS has faced in the study of the environmental license granted to CHEC and in the process of granting the environmental license to ISAGEN are technical and scientific ignorance within CORPOCALDAS on the subject of geothermal energy and the spatial superposition of the projects presented by ISAGEN and CHEC 
(Figure 2). These issues were presented as barriers that slow the establishment of the geothermal projects led by these companies.

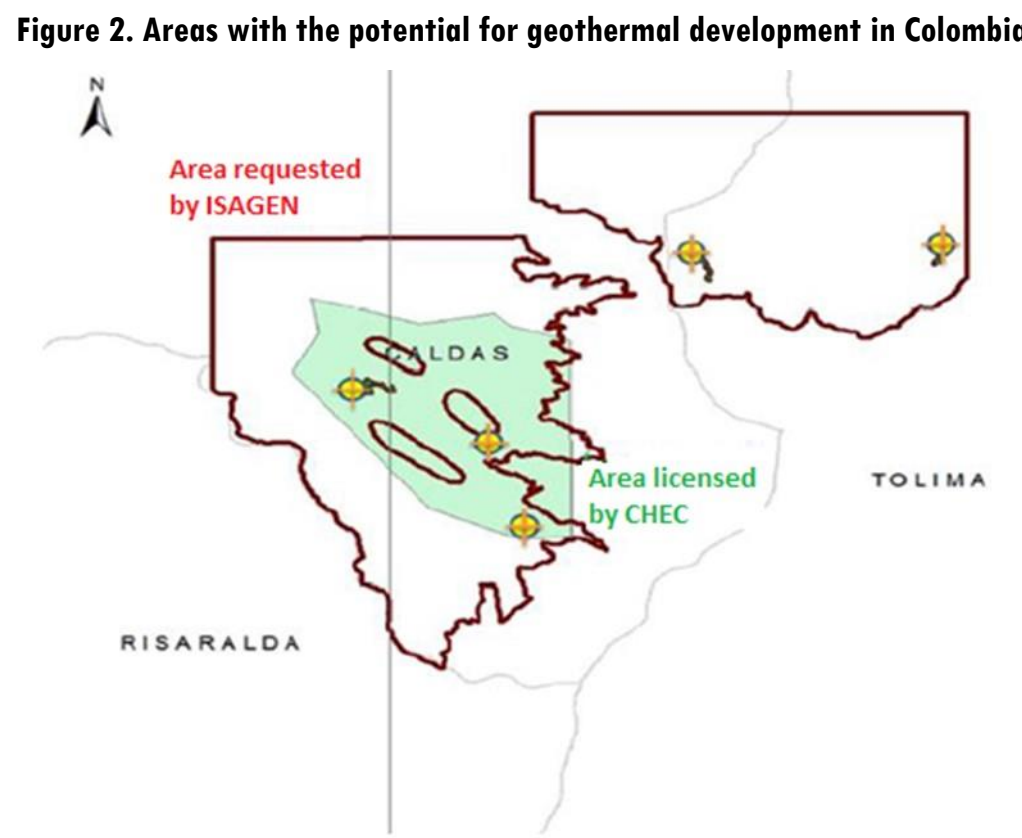

Source: Ramírez Baena [24].

In 2015, CHEC formed an alliance with LAGEO, a Salvadoran company with extensive experience in the development and operation of geothermal projects, to improve knowledge in the Nereidas Valley and to design and build 3 deep wells from 2016 to 2018 [25]. On the other hand, ISAGEN intended to assess the deposit through exploratory drilling between 2013 and 2017 and to design the geothermal plant. In addition, ISAGEN aims to build and operate the geothermal plant between 2017 and 2021 [26]. However, due to the abovementioned problems, the company does not yet have an environmental license for the proper development of the project.

According to the contributions of the SGC at RENAG 2017 [27], the fields of study in which work has already been performed for the Nevado del Ruiz are geology and water geochemistry. Moreover, there have been advances in gravimetry, magnetometry, 2D magnetotelluric modeling, 2D geothermal modeling, conceptual modeling, and the mapping of the geothermal area. Finally, the SGC mentions that more specific studies regarding structural geology, temperature soundings, 3D magnetotelluric models, diffuse gases and gas geochemistry (Radon) are still pending. In 2018, the SGC planned to perform or complete magnetotelluric studies, water and gas geochemistry, and the mapping of the geothermal area [27]. 
The quantity and diversity of studies that have been performed since 1968 to study the potential and utilization of the geothermal resources at NRV makes this area the most researched geothermal zone in Colombia.

Currently, the largest and most ambitious hydroelectric construction project in Colombia, Hidroituango, has been under a state of emergency since April 28, 2018, when a landslide occurred in the bypass tunnel, generating a high risk of flooding for the communities downstream from the dam [28]. This project is led and developed by the EPM, which, similar to the CHEC, is part of the EPM business group. Due to the large sums of money that the EPM group has had to pay as penalties and compensation to the community, the group has resorted to selling assets to guarantee its liquidity, cutting costs within the company organization, and stopping all new investments in electricity generation projects [29]. On the other hand, due to the recent sale of ISAGEN stock held by the Colombian government, investment plans and the development of new generation projects may be affected. The current situation regarding the two companies most heavily invested in the development of the geothermal project in the Nevado del Ruiz volcano may slow the development of this project.

\section{Tufiño-Chiles-Cerro Negro Volcanoes}

\section{Previous studies}

In 1978, the first geothermal reconnaissance activities were developed by the Ecuadorian Electrification Institute (INECEL), which performed a regional geological survey and created an inventory of thermal manifestations in the area. The following year, in 1979, OLADE developed a geothermal recognition study in Ecuador, where the geovolcanic and hydrogeochemical conditions of the Tufiño-Chiles-Cerro Negro area were found favorable for the existence of geothermal systems [30].

In 1982, OLADE, in collaboration with INECEL and Geotérmica Italiana, developed a study on the use of the geothermal resources of the Tufiño area corresponding to the first phase of a pre-feasibility study for this area, where possible regional thermal anomalies were specified and geothermal models were proposed for the Tufiño-Chiles-Cerro Negro volcanic complex [31].

In 1983, ICEL (Colombian Institute of Electric Energy) presented a preliminary prefeasibility report, Phase I, describing the geovulcanology of the Chiles-Cerro Negro, Cumbal 
and Nasate volcanic systems, analyzing their thermal sources, hydrothermal alteration, structures, hydrology, geochemistry, and water classification and presenting a scheme of possible geothermal systems [32]. This same year, OLADE, in collaboration with INECEL, ICEL and Geotérmica Italiana, presented a report describing volcanism in the Quaternary and, in particular, the stratigraphic succession of the Chiles-Cerro Negro volcanic complex [33].

In 1987, a pre-feasibility study was presented by the Aquater Consulting Agency. This study defined two possible horizons for producing geothermal fluids: a deep reservoir with an approximate depth of $2000 \mathrm{~m}$ and temperatures $>200^{\circ} \mathrm{C}$ and a shallow reservoir ranging from 500-1000 m deep with temperatures approximately $150^{\circ} \mathrm{C}$ [30], [34].

For approximately 2 decades (1990-2009), this binational geothermal project was stalled for political reasons. The project was resumed in 2009 when HIGGECO Cia. Ltda. drilled the first vertical gradient, known as PGT-1, which reached a depth of $554.30 \mathrm{~m}$; however, its temperature was not measured [33].

In July 2010, a binational agreement was signed between the governments of Colombia and Ecuador for the generation of electricity by geothermal energy. In the execution of this agreement, in 2012, ISAGEN and Corporación Eléctrica del Ecuador (CELEC) signed a specific technical cooperation agreement with the purpose of continuing the pre-feasibility studies of the Tufiño-Chiles-Cerro Negro binational geothermal project. The area where the project would be developed covers approximately 49000 hectares, with an estimated generation capacity of $138 \mathrm{MW}$ [7].

In 2015, ISAGEN and CELEC presented a report containing geological maps at a 1:10,000 scale, hydrothermal alterations, and structural information for the area. In addition, ISAGEN and CELEC performed 10 radiometric data measurements and re-logged the PGT-1 well. This report mentions that geophysical studies were not performed to define the reservoir because the community in the Colombian territory did not authorize these studies [33], [35].

Bocanegra and Sánchez [36] mapped the faults found in the region of interest for the binational geothermal project based on data mining and in-field validations. In the same year, Chancusig [33] characterized the lithostratigraphic sequence and the mineralogy of the hydrothermal alteration of the PGT-1 well, and the results validated the conceptual geothermal model proposed in 1988. 


\section{Current situation and projections}

Currently, the binational project for electric generation through geothermal energy from the Tufiño-Chiles-Cerro Negro volcano is in the pre-feasibility stage and is led by the ISAGEN and CELEC companies. This binational agreement is expected to terminate in 2018. However, taking into account the sale of Colombian participation in ISAGEN and the project's status as part of a binational agreement, ISAGEN, in its 2016 growth management report [37], requested that the Ministry of Mines and Energy designate another government entity to provide continuity to the binational geothermal project, with which they would liaise in terms of investments made. This request adds to some of the problems that have been presented in terms of the affected communities and hinders the anticipated development of the Tufiño-Chiles-Cerro Negro binational geothermal project.

\section{Azufral Volcano}

\section{Previous studies}

Interest in the geothermal area of the Azufral volcano began in 1982 with the OLADE report on geothermal resources in Colombia, which classified this area as a high priority for the possible development of a geothermal project [38]. As of this year, the SGC has developed and supported numerous studies with the objective of identifying the geothermal potential of this area. Cepeda et al. [39] conducted a study that involved the chemical and petrographic characterization of the Azufral, Cumbal, and Chiles-Cerro Negro volcanoes. Studies were performed on the activity of the Azufral volcano and its petrological, vulcanological, and geochemical evolution [40]-[43], and a first Visit and Recognition Report was presented on the geothermal pre-feasibility of the Azufral volcano by Calvache et al. [44] (as Phase 1). Between 1997 and 2002, numerous studies were carried out on the geology, stratigraphy, pyroclastic products, and volcanic deposits of the Azufral volcano [45]-[49] in addition to a geochemical study of the geothermal system of the Azufral volcano [50].

Between 2005 and 2007, a series of field studies were performed to collect gravimetric, magnetometric, geoelectric, and seismic data, which were described in the Underground Water Exploration project of the SGC in collaboration with the National University of Colombia. Some of these works are the Gravimetric Study of the Hydrogeological Basin of the Guachucal-Azufral Valley, Nariño, and the Nariño highlands [51], [52]; the Structural Scheme for the Hydrogeological Exploration in the Nariño highlands [53]; the interpretation of the geochemical information of thermal outcrops in Colombia [54]; and Magnetometry Applied to groundwater Exploration in Nariño [55]. 
Carvajal et al. [56] presented the first geothermal model of the Azufral volcano created by identifying hydrothermal alteration zones, which illustrated a mature high-temperature geothermal system $\left(>250^{\circ} \mathrm{C}\right)$ with a localized magmatic heat source located mainly to the east of the volcano. These results were consistent with a geochemical model based on the distribution and characterization of the thermal and fumarole manifestations of the Azufral volcano [56].

Ponce [57] published a study on the exploration of the geothermal resources of the Azufral volcano from the interpretation of potential field anomalies. Ponce found an area where geothermal gradients vary between $120^{\circ} \mathrm{C} \mathrm{km}^{-1}$ and $250^{\circ} \mathrm{C} \mathrm{km}^{-1}$, in addition to low-density lithologies that would probably allow for the presence of hot fluids. This observation demonstrated the possible existence of a geothermal field of medium-to-high temperature in the Azufral volcano's influence area.

In 2015, Alfaro et al. [58] presented a preliminary conceptual model of the Azufral geothermal system based on an integration of existing studies that included seismic information from the volcanic activity monitoring program. This study concluded that a hightemperature geothermal system, with a temperature close to $225^{\circ} \mathrm{C}$, dominates the current activity of the Azufral volcano. The thermal manifestations and hydrothermal surface alterations are mainly governed by faults and their intersections. The geothermal reservoir is possibly 2-2.5 km deep. The discharge zones are favored by faults with NW-SE orientations, which transport fluid from the center of the volcanic building $6-8 \mathrm{~km}$ to the east, where they accumulate. Finally, the authors mentioned that the geothermal fluid obtains an important contribution of surface water throughout its ascent.

\section{Current situation and projections}

According to the SGC at RENAG 2017 [27], a project in the geothermal area of the Azufral volcano is in pre-feasibility status. The fields of study in which work has already been performed are geology, gravimetry, magnetometry, structural geology, temperature sounding, 2D and 3D magnetotelluric modeling, and water geochemistry. It was mentioned that 3D geological and conceptual models are currently under way, in addition to gas geochemistry and diffuse gas (Radon) studies and the mapping of the geothermal area. By 2018, the SGC is expected to complete the gas geochemistry studies, the 3D geological model, and the mapping of the geothermal area. 


\section{Paipa geothermal area}

\section{Previous studies}

The first study in the Paipa geothermal area was conducted by Boussingault and Roulín [59], who performed a chemical analysis of the thermal waters and described the area's high salinity. Navia and Barriga [60] gave a geological description of the area, in which they revealed the existence of salt banks, included the physicochemical and radioactive characterizations of some of the thermal outcrops, and performed a beneficial study of the waters. In these studies, the geothermal energy production potential of the Paipa area was not mentioned.

In the study published by OLADE in 1982 on the recognition of Colombia's geothermal resources, the Paipa area was mentioned as an area with geothermal potential of medium to high priority, mainly due to geological criteria, such as the existence of volcanic rings of pyroclastic deposits, the phenomena of hydrothermal alteration, the existence of rocks of rhyolitic composition, the alkaline character, and the its age of 2.5 million years. This study also classified the hot springs according to their chemical composition [38].

In 1983, ICEL asked the Japan Consulting Institute to conduct a preliminary feasibility study for the construction of a geothermal plant in Boyacá. This study concluded that although some geothermal reservoirs may be suitable for exploitation, more advanced exploration activities were required [61].

Ferreira and Hernández [62] defined geothermal systems based on their geology and geochemistry and on the stable isotope analysis of water and gases, identifying these systems as heat sources due to magmatic intrusion within a sedimentary sequence; a reservoir of primary porosity in sedimentary formation (Une); a shallow reservoir with secondary permeability in fractured rocks; a clay seal layer (Churuvita Group); a primary permeability recharge zone; and a discharge zone fed by deep fluids flowing through a normal fault with $\mathrm{NE}-\mathrm{SW}$ orientation. In addition, a reservoir temperature exceeding $200^{\circ} \mathrm{C}$ was estimated using alkaline geothermometers.

Bertrami et al. [63] mentioned the existence of a high-temperature geothermal system in the Paipa area based on the chemical and isotopic composition of the aqueous and gaseous phases of the thermal outcrops in the area.

Several studies have been performed since 2002 by SGC (formerly INGEOMINAS), with the purpose of better understanding the geothermal system in the Paipa area. Alfaro [64] and 
[65] developed studies on the aqueous-phase geochemistry of thermal outcrops, and Velandia [66] developed a technical report on the geological and structural cartography of the area at a scale of 1:25000.

Alfaro et al. [67] formulated a preliminary conceptual geothermal model based on the integration of existing geological, geophysical, and geochemical studies, wherein they concluded that the heat source in the Paipa area is magmatic with an age under 2.5-2.1 million years and that it is related to the Paipa volcano. The study noted that the reservoir is probably located in a caldera, approximately $3 \mathrm{~km}$ in diameter, formed by the Paipa volcano, which is probably associated with normal faults such as the Paipa-Iza and the Cerro Plateado and surrounded by areas fractured by the ascent of magma and/or water. Finally, the authors noted that the discharge area is structurally controlled, mainly in the ITP-Laceros sector.

In recent years, resistivity and geophysical, gravimetry and magnetometry studies have been performed [68]-[71], which could be integrated and could contribute to the revision of the existing geothermal model.

The SGC organized a symposium in 2016 to celebrate 100 years of scientific production, where the geothermal conceptual model of the Paipa geothermal area was updated by the Geothermal Resource Exploration group [72].

\section{Current situation and projections}

According to the SGC at RENAG 2017 [27], the project in the Paipa geothermal area is in pre-feasibility status. The fields of study in which work has already been performed are geology, gravimetry, magnetometry, structural geology, temperature sounding, 2D and 3D magnetotelluric modeling, water geochemistry, 3D geological modeling, and conceptual modeling. In addition, the SGC mentioned that they have made progress in the geochemistry of gases and diffuse gases (Radon) and in mapping the geothermal area. For the current year, 2018, the SGC intends to conduct gas geochemistry studies and work on the mapping of the geothermal area in addition to drilling two boreholes in deep ravines and saltpeter paths, where each hole will have a depth of $500 \mathrm{~m}$, according to the socialization performed in the area of influence. 
Table 1. Summary of existing scientific studies for the geothermal areas previously described

\begin{tabular}{|c|c|c|c|c|c|}
\hline \multicolumn{2}{|c|}{ Scientific Studies } & $\begin{array}{l}\text { Nevado del } \\
\text { Ruiz volcano } \\
\text { (NRV) }\end{array}$ & $\begin{array}{c}\text { Tufiño-Chiles- } \\
\text { Cerro Negro } \\
\text { volcanoes }\end{array}$ & $\begin{array}{l}\text { Azufral } \\
\text { volcano }\end{array}$ & $\begin{array}{c}\text { Paipa } \\
\text { geothermal } \\
\text { area }\end{array}$ \\
\hline \multicolumn{2}{|l|}{ Geology } & $*$ & $*$ & $*$ & $*$ \\
\hline \multicolumn{2}{|c|}{ Structural Geology } & $*$ & $*$ & $*$ & $*$ \\
\hline \multicolumn{2}{|l|}{ Gravimetry } & $*$ & $*$ & $*$ & $*$ \\
\hline \multicolumn{2}{|l|}{ Magnetometry } & $*$ & $*$ & $*$ & $*$ \\
\hline \multirow{2}{*}{ Magnetotelluric } & 2D Model & $*$ & $*$ & $*$ & $*$ \\
\hline & 3D Model & - & - & $*$ & $*$ \\
\hline \multirow{3}{*}{$\begin{array}{l}\text { Geochemistry } \\
\text { Fluids }\end{array}$} & Water & $*$ & $*$ & $*$ & $*$ \\
\hline & Gases & $*$ & - & $*$ & $*$ \\
\hline & Diffuse Gases & - & - & $*$ & $*$ \\
\hline \multicolumn{2}{|c|}{ 3D Geological Model } & $*$ & - & $*$ & $*$ \\
\hline \multicolumn{2}{|c|}{ Conceptual Model } & $*$ & $*$ & $*$ & $*$ \\
\hline \multicolumn{2}{|l|}{ Geothermal Map } & $*$ & - & $*$ & $*$ \\
\hline
\end{tabular}

Table 1 shows a summary of existing scientific studies (finalized or ongoing) for the previously described geothermal areas. Most of the existing studies in the Azufral Volcano and Paipa are being conducted or guided by SGC. In the case of NRV, studies are being conducted by SGC, ISAGEN and CHEC. Finally, in the case of the Tufiño-Chiles-Cerro Negro volcanoes, most of the studies are being or were conducted by ISAGEN and CELEC EP.

\section{Other potential geothermal areas}

According to a study performed by OLADE in 1982 [38] and the geothermal research plan developed by the SGC, there are other areas in Colombia that are deemed potentially suitable for the development of geothermal energy generation projects: the San Diego volcano area, the Cerro Machín volcano, the Santa Rosa de Cabal area in the department of Risaralda, the Galeras volcano area, Cumbal, and Puracé, among others. Most of these projects are in the exploration stage, except for the San Diego volcano area, which is in the early pre-feasibility stage. The SGC is the entity that leads most of the exploration and recognition of geothermal resource projects in Colombia.

\section{Current geothermal uses in Colombia}

Applications of geothermal resources are very diverse and depend mainly on the characteristics of geothermal fluids and their heat content or enthalpy (Figure 3) [73]. Hightemperature or high enthalpy $\left(>150^{\circ} \mathrm{C}\right)$ geothermal resources are required for the production of electricity. These resources can be considered scarce compared to resources having 
medium $\left(90^{\circ} \mathrm{C}-150^{\circ} \mathrm{C}\right)$ and low temperatures $\left(<90^{\circ} \mathrm{C}\right)$; thus, there are other applications of geothermal energy that are termed direct uses or applications [74].

The steam, heat, or hot water from geothermal reserves can be used directly in industrial applications, greenhouses, residential applications, and services, among others; for example, some of the applications are the drying and the sterilization of industrial products, washing, heating greenhouses, and heating and cooling housing developments through the use of heat pumps [75].

Figure 3. Uses of geothermal resources according to their temperature

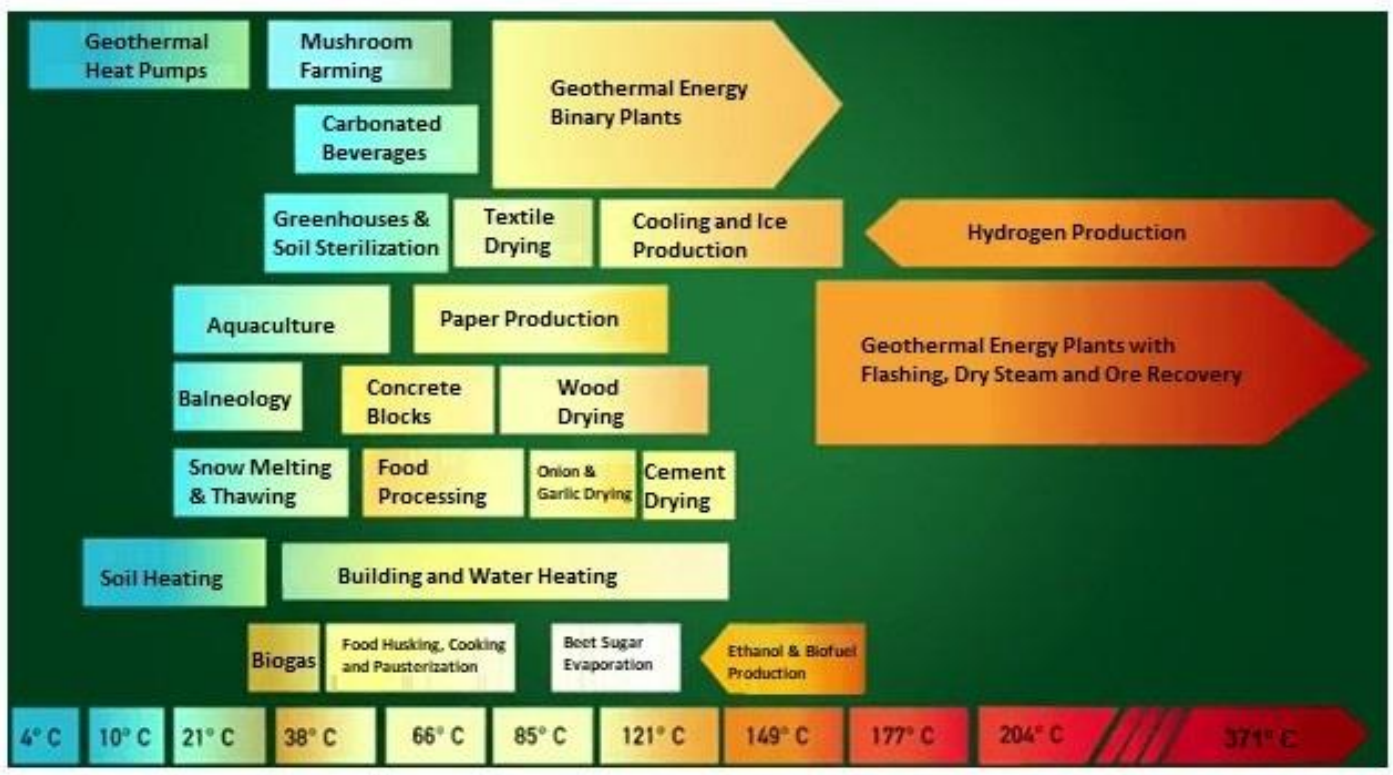

Source: Prol Ledesma [76].

Based on the projects already documented, resorts and tourist services are predominant and are almost the only applications for geothermal resources in Colombia. These projects have been developed in departments, such as Cundinamarca, Boyacá, North Santander, Antioquia, Caldas, Risaralda, Tolima, Cauca, Nariño, Putumayo, Magdalena, and Chocó [77]. There are also other direct-use projects that have been developed privately without records or documentation; thus, it is not possible to make an accurate inventory of direct-use geothermal projects in Colombia. For example, the use of geothermal heating at Hacienda La Quinta near NRV was not documented (Figure 4A).

Currently, SAGG SAS, a company that promotes the development of low-enthalpy geothermal projects in Colombia via the installation of geothermal heat pumps, has become the first company that has acquired the tax benefits for the employment and development of 
geothermal projects as a source of unconventional renewable energy mentioned in Law 1715 of 2014 (Figure 4B) [78].

Figure 4. A) Use of geothermal heating at Hacienda La Quinta near the NRV geothermal area. B) Cold room with a geothermal heat pump pilot project developed in Bogotá by SAGG SAS

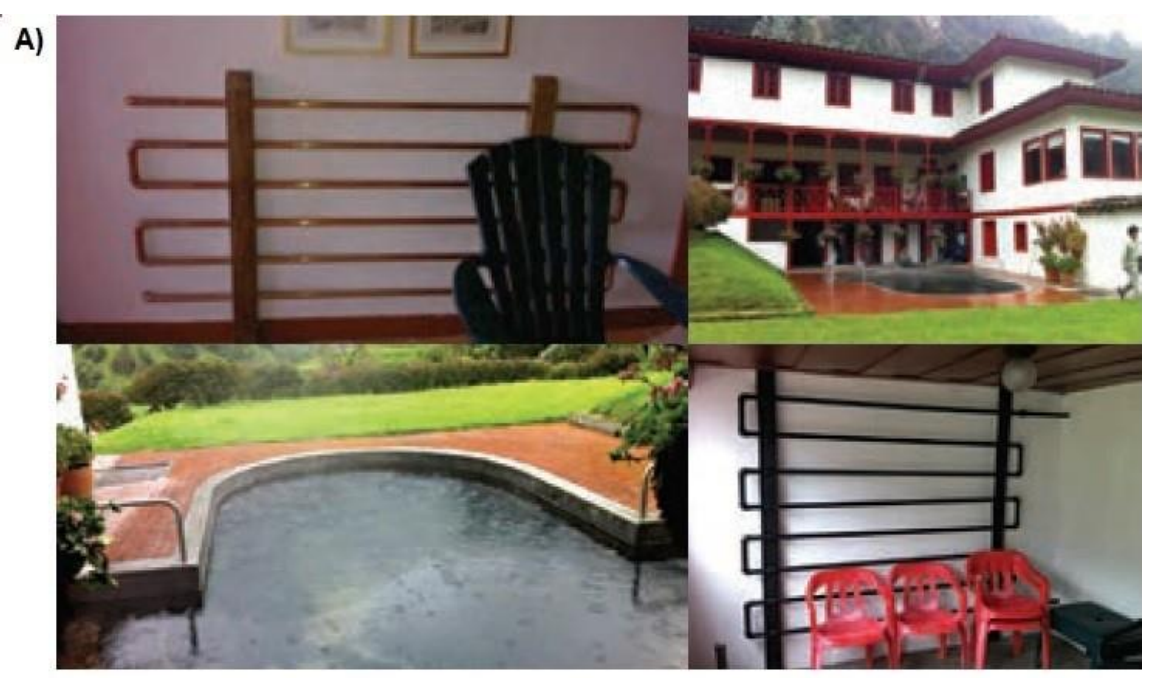

B)

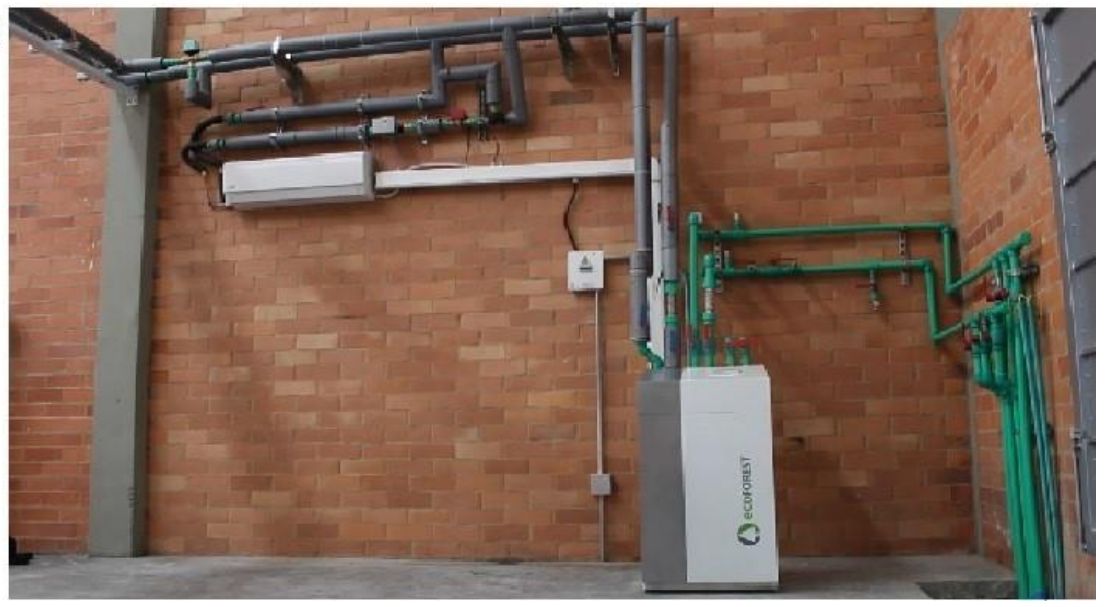

Source: Marzolf [74] and Ortiz [78].

\section{Regulatory framework}

The legal advances that have been developed to date with respect to geothermal energy in Colombia are framed in the following regulations:

Executive Order 2811 of 1978: National Code of Natural Resources

Articles 172 and 173 define geothermal resources as natural or injected water in an underground endogenous heat source resulting in the spontaneous or induced production of 
hot springs or steam. Geothermal resources are also those that emerge naturally or by human effort with a temperature higher than 80 degrees Celsius. Geothermal resources that do not reach a minimum temperature of 80 degrees Celsius shall not be considered hot springs.

Article 175 discusses the uses of geothermal resources, such as energy production, cooling and heating, and extraction of minerals.

Articles 176 and 177 describe the permits required for the exploitation of geothermal sources. In addition, these articles mention that those requesting exploration permits shall be responsible for taking the necessary measures to eliminate the polluting effects of water or condensed vapors.

\section{Law 99 of 1993: Creation of the SINA}

Articles 23 and 31 define Regional Autonomous Corporations as agencies appointed by law to manage, monitor, and control, within the area of their jurisdiction, both the environment and renewable natural resources and to strive for their sustainable development. These functions include the issuance of the proper environmental licenses, permits, concessions, authorizations, and laissez-passer documents.

Article 50 defines environmental licenses as authorization granted by a competent Environmental Authority for the execution of a work or activity, subject to compliance with the established requirements in relation to the prevention, mitigation, correction, compensation, and management of environmental effects from the authorized works or activities.

\section{Law 697 of 2001: Law on the rational and efficient use of energy}

This law includes geothermal energy as a renewable source of energy.

\section{Law 1715 of 2014}

This law integrates non-conventional renewable energies into the national energy system. This law declares these as energies of national interest, essential to guarantee the supply of energy. This law establishes fiscal incentives to encourage research, development, and investment in the sector of non-conventional sources of energy (nuclear, biomass, small 
hydroelectric, wind, geothermal, solar, and tidal). These incentives allow for the deduction of $50 \%$ of the investments made during 5 years from annual income; value-added tax (VAT, known as IVA in Colombia) exemption on local or imported equipment, items, machinery, and services destined for pre-investment and investment activities; and tariff incentives and the accelerated depreciation of assets [79].

\section{Executive Order 2143 of 2015}

This executive order is the single regulatory decree that defines the guidelines for the application of incentives provisioned in Law 1715 of 2014. This executive order specifically explains the requirements and the scope of the benefits, such as a special deduction on income and supplementary taxes, VAT exclusions, tariff levy exemptions, and the tariff depreciation regime, in addition to describing the procedures required and their intended addressees.

Executive Order 1076 of 2015: Sole regulatory decree for the environment and sustainable development sector

This executive order defines the competence of the Regional Autonomous Corporations as the environmental authority for the exploration, construction, and use of generating plants and virtually polluting sources with an installed capacity equal to or greater than $10 \mathrm{MW}$ and less than $100 \mathrm{MW}$. Projects with an installed capacity greater than or equal to $100 \mathrm{MW}$ will be overseen by the National Agency for Environmental Licenses (ANLA), an autonomous government authority that provides permissions for the development of projects that significantly impact the environment.

\section{Resolution 045 of 2016-UPME-MINMINAS}

This resolution establishes the procedures and requirements for issuing certifications and endorsing projects from Non-Conventional Sources of Energy, seeking to obtain the benefits of VAT exclusion or exemptions from the tariff charges provisioned in Articles 12 and 13 of Law 1715 of 2014, and determining the expiration date of these certifications and their renewal procedures, among other provisions. 


\section{Resolution 1283 of 2016}

This resolution establishes the procedure and requirements for the issuance of the environmental benefit certification for new investments in Non-Conventional Sources of Renewable Energy and efficient energy management projects to obtain the tax benefits provisioned in articles 11, 12, 13, and 14 of Law 1715 of 2014 and other determinations as adopted.

\section{Resolution 585 of 2017: UPME}

This resolution details the VAT exclusion procedure at UPME.

\section{Resolution 2000 of 2017: Ministry of the Environment}

This resolution details the VAT exclusion procedure at ANLA.

To summarize, Executive Order 2811 of 1974 defines geothermal resources; Law 99 of 1993 creates the Environmental Authorities and their instruments for the authorization, control, and monitoring of the exploitation of geothermal resources; Executive Order 1076 of 2015 defines the competence of the Environmental Authorities for Resource Generation and Use projects; Law 1715 of 2014, Executive Order 2143, Resolutions 045 and 1283 of 2016, and Resolutions 585 and 2000 of 2017 define geothermal energy incentives and the corresponding procedures to secure them for a given project.

\section{Geothermal development limitations in Colombia}

Considering the contributions from the CHEC and ISAGEN companies, the SGC, and Environmental Authorities, such as CORPOCALDAS and ANLA at RENAG 2016 and 2017, as well as the studies performed by the Inter-American Development Bank on the subject, some barriers that restrain the development of geothermal projects in Colombia are

- The limited technical and scientific knowledge of the Environmental Authorities, which delays the study and authorization of environmental permits for the development of projects. 
- The preliminary exploration phases involving high risks and investments, which requires financial assistance.

- The limited infrastructure, specialized equipment, and labor for the exploration and development of geothermal projects.

- The location of geothermal areas in volcanic areas without any infrastructure that may allow access and connection to the National Transmission System.

- The lack of adequate legislation that allows for the development and exploitation of geothermal resources and their efficient and effective participation in the energy market.

- The lack of knowledge on the part of society and political communities about the benefits of the development of geothermal energy, such as the reduction of electrical system vulnerability to the effects of climatic variations, the diversification of the energy source, the reduction of greenhouse gas emissions, and the reduction in the demand and consumption of fossil fuels.

- The current uncertainty about the conditions of the main companies that promote geothermal energy in Colombia, such as ISAGEN and CHEC.

\section{Recommendations}

Given the limitations discussed in the previous session, it is important to mention some solutions that promote the implementation of geothermal energy in the Colombian energy store, including energetic and direct uses. Some of these possible solutions are:

- Develop synergy and communication among communities, government institutions, local and international companies and academic entities, in order to carry out projects and exchange knowledge about geothermal energy.

- Offer appropriate education in the national education system to promote the development of renewable energies, such as geothermal resources; it is important to inform communities and companies about the benefits and impacts, positive and negative, which may result from the development of this energy source.

- Promote international cooperation to share technical knowledge and social experiences with communities, to contribute to the implementation of geothermal projects. 
- Develop a normative and regulatory framework that offers clarity to people and companies interested in making use of this resource. This framework should be based on knowledge gained from other countries that have developed this source of energy.

- Promote open information related to geothermal projects in Colombia, so other researchers, communities and groups of interest can find high-quality information to build new knowledge.

- Create a national database that allows for the sharing of experiences that have been developed through different geothermal projects, including energetic and direct uses, in order to know the real costs of their investment and operation, their success or failure, and the problems that have been faced and the solutions that have been found.

Finally, it is important to mention that the Colombian Geothermal Association was founded in 2017. This association is a scientific, educational, and professional nonprofit organization, headquartered in Bogotá city, whose main purpose is to facilitate interaction between communities, government, industry and academia, for the promotion of research, development and use of geothermal resources in Colombia.

\section{Conclusions}

Energy vulnerability in Colombia, in addition to a government policy of progressively fostering sustainable development in different territories, has continually generated favorable conditions for the exploitation of geothermal resources. Nevertheless, there are several technical, infrastructural, legal, and institutional barriers that hinder the proper development of these projects.

The use of geothermal resources will diversify the energy basket through the integration of renewable energy, thus reducing the energy vulnerability in Colombia caused by high dependence on hydroelectric energy, which is generally affected by climatic variations, particularly in times of drought.

Most recent studies and geothermal projects have been led and developed by various international, governmental, private, and academic entities, such as ISAGEN; the CHEC; the SGC; COLCIENCIAS; the Inter-American Development Bank; and OLADE. 
It is necessary to seek and obtain technical and economic cooperation at a national and international level that may contribute to the implementation of geothermal energy generation in Colombia. In addition, a review of the current regulations on the environmental and energy market would be required to determine whether the current legal conditions facilitate the proper integration of geothermal energy in the country's energy basket or whether regulations exclusive to geothermal energy may be required due to its wide differences from other Non-Conventional Sources of Renewable Energy.

\section{References}

[1] UPME, "Informe mensual de variables de generación y del mercado eléctrico colombiano." 2016 Available at: http://www.siel.gov.co/Inicio/Generaci\%C3\%B3n/Estad\%C3\%ADsticasyvariablesdegeneraci\%C 3\%B3n/tabid/115/Default.aspx?PageContentID=1191

[2] International Energy Agency (IEA),. .'Hydropower and the Environment: Survey of the environmental and social impacts and the effectiveness of mitigation measures in hydropower development." Technical Report, vol 1. pp 1-111, 2000.

[3] S. Algburi, Hydroelectric Power. Book: Energy Science \& Technology. Vol. 1: Opportunities and Challenges. Chapter: 17, “Hydropower”. Studium Press LLC, 2015, pp. 429-448.

[4] F. Faria, A. Davis, E. Severnini, and P. Jaramillo, "The local socio-economic impacts of large hydropower plant development in a developing country." En. Econ, no. 67, 2017. https://doi.org/10.1016/j.eneco.2017.08.025.

[5] E. Barbier, "Geothermal energy technology and current status: an overview." Renew. Sust. Energ. Rev., no. 6, pp. 3-65, 2002.

[6] C. Alfaro, "Improvement of perception of the geothermal energy as a potential source of electrical energy in Colombia, country update." Paper presented at the World Geothermal Congress, Melbourne, Australia, 2015.

[7] E. Mejía, L. Rayo, J. Méndez, and J. Echeverri, “Geothermal development in Colombia.” Paper presented at the Short Course VI on Utilization of Low- and Medium-Enthalpy Geothermal Resources and Financial Aspects of Utilization, Santa 5Tecla, El Salvador, pp. 1-7, 2014.

[8] C. Alfaro, N. Bernal, G. Ramírez, and R. Escobar, “Colombia, Country Update.” Paper Presented at the proceedings World Geothermal Congress. Kyushu, Tohoku, Japan. pp. 1-10, 2000.

[9] CHEC, ICEL, Consultoría Técnica Colombiana Ltda., Geotérmica Italiana, "Investigación geotérmica macizo volcánico del Ruiz. Fase II, Etapa A.”

[10] M.L. Monsalve, G.I. Rodríguez, R.A. Méndez, and N.F. Bernal, “Geology of the Well Nereidas 1, Nevado del Ruiz Volcano,” Colombia Geothermal Resources Council. no. 22, pp. 263-268, 1998.

[11] INGEOMINAS, Mapa geotérmico de Colombia. Bogotá D.C., 2000.

[12] J.A. Forero, “Caracterización de las alteraciones hidrotermales en el flanco Noroccidental del Volcán Nevado del Ruiz, Colombia.” MSc thesis, Universidad Nacional de Colombia, Bogotá, 2012. 
[13] E. Mejía, F. Velandia, C. Zuluaga, J. López, and T. Cramer, “Análisis estructural al noreste del Volcán Nevado del Ruíz, Colombia - Aporte a la exploración geotérmica.” Bol. Geol, vol. 34, no. 1, pp. 27-41, 2012.

[14] L. Rayo Rocha, "Evolución geoquímica y térmica del volcán Nevado del Ruiz, Colombia." MSc thesis, Universidad Nacional de Colombia. Bogotá D.C, Colombia. pp. 1-70, 2012.

[15] O.E. Rojas, "Contribución al modelo geotérmico asociado al sistema volcánico Nevado del RuizColombia, por medio del análisis de la relación entre la susceptibilidad magnética, conductividad eléctrica y térmica del sistema." MSc thesis, Universidad Nacional de Colombia, Bogotá, 2012.

[16] L.J. Almaguer, "Estudios magnetotelúrico con fines de interés geotérmico en sector Norte del Nevado del Ruíz, Colombia.” MSc thesis, Universidad Nacional Autónoma de México, 2013.

[17] J. González-Garcia, and M. Jessell, “A 3D geological model for the Ruiz-Tolima Volcanic Massif (Colombia): Assessment of geological uncertainty using a stochastic approach based on Bézier curve design." Tectonophysics, vol. 687, pp. 139-157, 2016.

[18] M.I. Vélez, D. Blessent, S. Córdoba, J. López-Sánchez, J. Raymond, and E. Parra-Palacio, “Geothermal potential assessment of the Nevado del Ruiz volcano based on rock thermal conductivity measurements and numerical modeling of heat transfer." J. S. Am. Earth Sci., no. 81, pp. 153-164, 2017.

[19] D. Ceballos, "Análisis geológico y estructural detallado de una zona del proyecto geotérmico en el valle de Las Nereidas, macizo volcánico Nevado del Ruiz, para contribuir en el proceso de exploración geotérmica, CHEC.” Universidad de Caldas, Manizales, 2017.

[20] J.A. Ossa, "Cartografía detallada de un área del proyecto geotérmico." Informe de pasantía para optar al título de geólogo, Universidad de Caldas, Manizales, 2018.

[21] D. Moreno, J. Lopez-Sanchez, D. Blessent, and J. Raymond, "Fault characterization and heat-transfer modeling to the Northwest of Nevado del Ruiz Volcano." J. S. Am. Earth Sci., vol. 88, pp 50-63, 2018.

[22] CHEC, "Geotermia: desafíos, mitos y realidades." Conferencia presentada en la Reunión Nacional de Geotermia (RENAG) 2016, Bogotá.

[23] ANLA, Auto No: 5731, 2014.

[24] A.F. Ramírez Baena, "Licenciamiento ambiental de proyectos geotérmicos avances y retos." CORPOCALDAS, Subdirección Evaluación y Seguimiento Ambiental, Conferencia presentada en la Reunión Nacional de Geotermia (RENAG) 2017, Manizales.

[25] J. López, "Geotermia: desafíos, mitos y realidades. Central Hidroeléctrica de Caldas, Instituto Colombiano de Energía Eléctrica (CHEC)." Conferencia presentada en la Reunión Nacional de Geotermia (RENAG) 2016, Bogotá.

[26] ISAGEN, “Actualidad y experiencias en Geotermia.” Conferencia presentada en la Reunión Nacional de Geotermia (RENAG) 2016, Bogotá.

[27] C. Alfaro, "Geotermia en Colombia: Proyecciones y plan de trabajo del Servicio Geológico Colombiano." Conferencia presentada en la Reunión Nacional de Geotermia (RENAG) 2017, Manizales.

[28] El País, "Cronología: esta es la historia de la crisis de Hidroituango que tiene en alerta al país." 2018. Available at: https://www.elpais.com.co/colombia/cronologia-esta-es-la-historia-de-la-crisis-dehidroituango-que-tiene-en-alerta-al-pais.html 
[29] EPM, “¿Por qué EPM va a vender algunos de sus activos?” Infográfico, 2018 [online]. Available: https://www.epm.com.co/site/Portals/0/Images/Infografico_PORTAFOLIO.png?ver=2018-0914-171552-957

[30] M.F. Coviello, "Proyecto OLADE/CEPAL/GTZ: Estudio para la evaluación del entorno del Proyecto Geotérmico Binacional 'Tufiño-Chiles-Cerro Negro',”. pp. 1-79, 2000.

[31] INECEL, OLADE, Geotérmica Italiana SRL, "Aprovechamiento de los recursos geotérmicos del área de Tufiño Chiles.” Informe técnico no publicado, 1982.

[32] ICEL, "Proyecto geotérmico Chiles-Cerro Negro, Fase I Etapa de prefactibilidad, Bogotá." Informe técnico no publicado, 1983.

[33] C.G. Chancusig Espinosa, "Caracterización de la secuencia litoestratigráfica y de la mineralogía de alteración hidrotermal del pozo PGT-1 del proyecto geotérmico Tufiño-Chiles, Provincia del Carchi.” Escuela Politécnica Nacional. Facultad de Ingeniería en Geología y Petróleos, Quito. 2017.

[34] OLADE, INECEL, ICEL, Aquater, "Investigación geofísica en el estudio de la prefactibilidad del Proyecto Geotérmico Binacional, Tufiño-Chiles." 1987.

[35] CELEC EP and ISAGEN, "Informe geológico parcial del Proyecto Geotérmico Binacional TufiñoChiles-Cerro Negro.” Informe Técnico Inédito del SYR, para CELEC-ISAGEN, 2015.

[36] L.C. Bocanegra and J.J. Sánchez, "Mapa de fallas de los volcanes Chiles-Cerro Negro (Nariño) a partir de minería de datos y confirmación de campo." Bol. Geol., vol. 39, no. 3, pp. 71-86, 2017.

[37] ISAGEN, “Informe de gestión 2016.” 2016 [online]. Available: https://www.isagen.com.co/informede-gestion/2016/

[38] OLADE, ICEL, GEOTÉRMICA ITALIANA, "Estudio de reconocimiento de los recursos geotérmicos de la República de Colombia." 1982.

[39] H. Cepeda, A. Acevedo, and L. Lesmes, "Características químicas y petrográficas de los volcanes Azufral, Cumbal y Chiles-Cerro Negro, Colombia.” Medellín: Ingeominas, 1987.

[40] F. Bechon, and M. Monsalve, "Activité récente préhistorique du volcan Azufral (S-W de la Colombie)." Comptes Rendus de l'Académie des Sciences, vol. 313, no. 1, pp. 99-104, 1991.

[41] T. Betancur, and A. Correa, "Estudio geológico de los depósitos piroclásticos proximales del volcán Azufral, Colombia.” Universidad Nacional de Colombia, Medellín, 1992.

[42] E. Fontaine and J. Stix, "Evolution pétrologique et geochimique du complexe de domes du volcan Azufral (Colombie, Amérique du Sud)." Comptes Rendus de l'Académie des Sciences, vol. 317, no. 11, pp. 1501-1508, 1993.

[43] E. Fontaine, "Evolution volcanologique et géochimique du Volcan Azufral, Colombie, Amérique du Sud." MSc Tesis, Universidad de Montreal, Canadá, 1994.

[44] M. Calvache, L. Bobadilla, F. García, A. Rivera, C. Angel, E. Chilito, et al. ,"Informe visita de reconocimiento, proyecto prefactibilidad geotérmica en el Volcán Azufral, Fase 1." Ingeominas, Bogotá, 1997.

[45] G. Cortés and M. Calvache, “Geología del volcán Azufral primera fase.” Ingeominas, Pasto, 1997.

[46] G. Cortés and N. Bernal, "Reconocimiento y cartografía de los depósitos volcánicos distales del Azufral.” INGEOMINAS, Manizales, 1998.

[47] M. Calvache, M.L. Monsalve, and P. Torres, "Informe preliminar proyecto evaluación de amenazas y 
riesgos volcánicos C99R06.” Ingeominas, Pasto, 2000.

[48] P. Torres, G. Cortés, M. Calvache and M.L. Monsalve, "Geología y estratigrafía del volcán Azufral, Colombia.” VIII Congreso Colombiano de Geología, Manizales, 2001.

[49] H. González, G. Zapata, and D. Montoya, "Geología y geomorfología de la plancha 428 Túquerres: Memoria explicativa, Nariño.” Ingeominas, Medellín, 2002.

[50] C. Alfaro, “Geoquímica del sistema geotérmico del volcán Azufral.” Ingeominas, Bogotá, 2001.

[51] N. Neiza, "Estudio gravimétrico de la cuenca hidrogeológica del Valle de Guachucal - Azufral, Nariño.” Ingeominas, Bogotá, 2006.

[52] M. Garzón, "Estudio gravimétrico en el altiplano nariñense.” Ingeominas, Bogotá, 2006.

[53] F. Velandia, D. Romero, B. Rodríguez, G. Hincapié, and E. Salazar, "Esquema estructural para exploración hidrogeológica en el altiplano nariñense," in Memorias, II Congreso Colombiano de Hidrogeología, Bucaramanga, 2006.

[54] A. Aguirre and R. Barragán, "Geochemical data interpretation of thermal springs in Colombia." Proceedings, Thirty-First Workshop on Geothermal Reservoir Engineering. Stanford: Stanford University, 2006. pp. 1-7.

[55] L. Vásquez, "Magnetometría aplicada a la exploración de aguas subterráneas en Nariño," in Memorias XI Congreso Colombiano de Geología, 2007.

[56] D. Carvajal, C. Alfaro, J. Molano, D. Romero, and J. Mojica, "Contribución al modelo geotérmico del volcán azufral a partir de identificación de zonas de alteración hidrotermal." Geol. Colomb., no. 33, pp. 99-108, 2008.

[57] P. Ponce, "Exploración de recursos geotérmicos del volcán Azufral a partir de la interpretación de anomalías de campos potenciales." MSc Thesis, Universidad Nacional de Colombia, Pasto, 2013.

[58] C. Alfaro, P. Ponce, M.L. Monsalve, I. Ortiz, J.V. Franco, A. Ortega, R. Torres, and D. Gómez, "A preliminary conceptual model of Azufral Geothermal System, Colombia." Proceedings World Geothermal Congress, 2015.

[59] J.B. Boussingault, and F.D. Roulín, Viajes científicos a los andes ecuatoriales. París: Librería Castellana, 1849.

[60] A. Navia and A. Barriga, Informe sobre las aguas termominerales de Paipa, Colombia. Gobernación de Boyacá. Bogotá: Imprenta Nacional, 1929.

[61] Japan Consulting Institute, "Feasibility study report of geothermal power plant for Instituto Colombiano de Energía Eléctrica (Electrificadora de Boyacá).” Bogotá, 1983.

[62] P. Ferreira and R. Hernández, "Evaluación geotérmica en el área de Paipa, basada en técnicas isotópicas, geoquímica y aspectos estructurales." Trabajo de grado, Universidad Nacional de Colombia, Departamento de Geociencias, Bogotá, 1988.

[63] R. Bertrami, A. Camacho, L. de Stefanis, T. Medina, and G.M. Zuppi, "Geochemical and isotopic exploration of the geothermal area of Paipa, Cordillera Oriental, Colombia." Estudios geotérmicos con técnicas isotópicas y geoquímicas en América Latina. OIEA, 1992.

[64] C. Alfaro, "Geoquímica del sistema geotérmico de Paipa." Informe Interno. Ingeominas, 2002.

[65] C. Alfaro, "Estudio isotópico de aguas del área geotérmica de Paipa." Informe interno. Ingeominas, 2002. 
[66] F. Velandia, "Cartografía geológica y estructural sector sur del municipio de Paipa.” Informe técnico, Ingeominas, 2003.

[67] C. Alfaro, F. Velandia, H. Cepeda, N. Pardo, L.E. Vásquez and O. Espinosa, "Modelo conceptual preliminar del sistema geotérmico de Paipa." Informe técnico. Ingeominas, Bogotá, 2005.

[68] L. Vásquez, "Aplicación geofísica de métodos potenciales en el área geotérmica Paipa-Iza-Servicio Geológico Colombiano.” Informe Técnico, Bogotá, 2012.

[69] I. Moyano, "Exploración geoeléctrica (sondeos eléctricos verticales y tomografías eléctricas) en el área geotérmica de Paipa (Boyacá).” Ingeominas, Bogotá, 2010.

[70] I. Moyano, "Modelamiento de estructuras geotérmicas ocultas a partir de la interpretación de anomalías magnetotelúricas de resistividad en la región de Paipa, Boyacá, Colombia." MSc thesis, Universidad Nacional de Colombia, 2015.

[71] D. Rojas, “Contribución al estudio del volcán de Paipa y su sistema termal mediante prospecciones de resistividad." MSc thesis, Universidad de los Andes, Bogotá, 2016.

[72] C. Alfaro, “Actualización del modelo geotérmico conceptual del área geotérmica de Paipa.” Simposio Grupo Exploración de Recursos Geotérmicos [online], 2016. Available at: https://www.youtube.com/watch?v=tPamolu81vQ \&t=4s

[73] G. Llopis and V. Rodrigo, Guía de la energía geotérmica. Madrid: Fenercom, 2008 [online]. Available: https://www.fenercom.com/pdf/publicaciones/guia-de-la-energia-geotermica.pdf

[74] N.C. Marzolf, Emprendimiento de la energía geotérmica en Colombia. Washington: Banco Interamericano de Desarrollo, convenio ISAGEN, 2014.

[75] IDAE and IGME, Manual de geotermia. Madrid, España, 2008.

[76] R.M. Prol Ledesma, Curso: introducción a la geotermia. México: Universidad Autónoma de México, 2017.

[77] M.A. Abril, "Estudio sobre la generación de energía geotérmica para su aprovechamiento en el sector de la construcción y las cimentaciones.” Monografía, Universidad Santo Tomás, Bogotá, 2017.

[78] A. Ortiz, "Caso exitoso en Colombia del aprovechamiento de la geotermia de baja entalpía para climatización," in Memorias de RENAG 2017. Manizales: SAGG, 2017.

[79] P. Bona and M.F. Coviello, Valoración y gobernanza de los proyectos geotérmicos en América del Sur. Washington: Comisión Económica para América Latina y el Caribe, 2016. 